\title{
PENGARUH KEMASAN TERHADAP MUTU SALE PISANG RAJA (Musa X paradisiaca AAB) SELAMA PENYIMPANAN
}

\author{
(The Effect of Packaging to Quality Sale "Raja” Banana \\ (Musa X paradisiaca AAB) During Storage)
}

\section{Andi Nur Faidah Rahman, Meta Mahendradatta, dan Jusmiati Effendi}

\author{
Program Studi Ilmu dan Teknologi Pangan, Departemen Teknologi Pertanian, Fakultas Pertanian, \\ Universitas Hasanuddin, Makassar 90245, Indonesia \\ *) email Penulis Korespondensi: faidah83@yahoo.com
}

\begin{abstract}
ABSTRAK
Sale pisang raja adalah produk hasil olahan pisang raja masak yang telah melalui proses pengeringan. Selama penyimpanan, sale pisang mengalami penurunan mutu dari segi komposisi kimia dan organoleptiknya. Sehingga diperlukan metode yang dapat mempertahankan mutu sale pisang raja selama penyimpanan dengan penerapan teknologi kemasan. Tujuan dari penelitian ini adalah untuk mengetahui pengaruh metode pengemasan (tanpa pengemasan, pengemasan HDPE dan pengemasan vakum HDPE) dan lama penyimpanan terhadap komposisi kimia dan kualitas organoleptik sale pisang raja. Desain penelitian ini terdiri atas dua faktor yaitu faktor kemasan dengan tiga taraf perlakuan (tanpa pengemasan, pengemasan HDPE dan pengemasan vakum HDPE) dan faktor lama penyimpanan dengan lima taraf perlakuan $(0,7,14,21$, dan 28 hari). Data diolah dengan menggunakan Rancangan Acak Lengkap (RAL) faktorial dengan tiga kali ulangan. Parameter kimia yang dianalisa adalah kadar air, kadar abu, gula reduksi, $\mathrm{pH}$, dan uji organoleptik (meliputi warna, aroma, rasa dan tekstur). Hasil penelitian menunjukkan bahwa penyimpanan pisang raja dengan kemasan vakum HDPE selama 28 hari memberikan hasil terbaik untuk semua parameter.
\end{abstract}

Kata Kunci : Pengemasan vakum, penyimpanan, sale pisang.

\section{ABSTRACT}

Sale raja banana are foods processed by mature banana which have been through the drying process. During storage, quality of sale raja banana decreased in terms of chemical composition and organoleptics. It is needed a method to maintain the quality of sale raja banana during storage by applying packaging technology. The purpose of this study was to determine the effect of packaging methods (without packaging, HDPE packaging and HDPE vacuum packaging) and storage time on the chemical composition and organoleptic quality of sale raja banana. The design of this study consisted of two factors: packaging using three treatment levels (without packaging, HDPE packaging, and HDPE vacuum packaging) and storage time with five levels of treatment $(0,7,14,21$, and 28 days). Data was processed using factorial Completely Randomized Design (CRD) with three replications. The chemical parameters analyzed were water content, ash content, reducing sugar, $\mathrm{pH}$, and organoleptic tests (including color, aroma, taste and texture). The results showed that the storage of sale raja banana with HDPE vacuum packaging for 28 days gave the best results for all parameters.

Keywords : Vacuum packaging, storage, sale banan 


\section{PENDAHULUAN}

Indonesia merupakan negara yang kaya akan komoditi hasil pertanian, salah satunya adalah pisang. Propinsi penghasil pisang terbesar selain pulau Jawa adalah Sulawesi Selatan (Satuhu \& Supriyadi, 1992). Pisang raja banyak diolah oleh masyarakat, karena rasanya manis dan aromanya kuat. Keunggulan pisang raja adalah dapat digunakan sebagai buah meja, dimana pisang dapat dimakan langsung setelah masak, maupun menjadi bahan baku produk olahan. Banyaknya pisang di Indonesia menyebabkan pisang memiliki nilai ekonomi yang rendah. Hal ini karena pisang memiliki kandungan air tinggi yang dapat mempercepat pembusukan, sehingga dapat menurunkan mutu buah pisang.

Pengeringan merupakan salah satu cara untuk mempertahankan daya simpan pisang. Produk olahan pisang yang diperoleh dari proses pengeringan yang banyak ditemukan di Sulawesi Selatan yaitu sale pisang. Sale pisang merupakan makanan hasil olahan pisang yang dibuat dari buah pisang segar yang telah masak (mature) dengan cara pengeringan. Selama proses pengeringan, berat buah pisang menurun dan berlangsung pula proses penguraian pati menjadi gula, sehingga meningkatkan kadar gula buah pisang. Hal ini menyebabkan sale pisang memiliki daya simpan yang lebih lama daripada pisang segar, rasanya lebih manis, serta dapat meningkatkan nilai ekonomi pisang.

Masyarakat umumnya menyimpan sale pisang tanpa dikemas atau dikemas dengan kurang baik, sehingga mudah terkontaminasi oleh kotoran dan mempercepat laju penyerapan air kembali setelah pengeringan, yang dapat menyebabkan perubahan mutu kimia maupun organoleptiknya dan mengurangi masa simpan sale pisang. Perubahan mutu sale pisang ditandai dengan perubahan kadar air karena sale pisang bersifat mudah menyerap air, adanya pelunakan, serta tumbuhnya mikroorganisme seperti khamir dan kapang.

Perbaikan mutu sale pisang perlu dilakukan guna meningkatkan nilai jualnya di pasaran. Penerapan teknologi kemasan merupakan salah satu metode yang dapat diterapkan untuk mempertahankan mutu sale pisang selama penyimpanan. Berdasarkan uraian di atas maka penelitian ini dilakukan untuk mengetahui pengaruh pengemasan HDPE (Hight Density Polyethylene) secara vakum, tanpa vakum, serta tanpa kemasan terhadap perubahan mutu kimia dan organoleptik sale pisang selama penyimpanan.

\section{METODOLOGI PENELITIAN}

\subsection{Alat}

Alat utama yang digunakan dalam penelitian adalah oven blower, pengemas vakum model DZ 280 A dengan kapasitas sampai dengan 0,35 Mpa dan alat penunjang lainnya seperti timbangan, $\mathrm{pH}$ meter, dan kelengkapan analisa kimia.

\subsection{Bahan}

Bahan utama yang digunakan adalah pisang raja masak (tingkat kematangan kulit buah kuning penuh) yang diambil dari kebun di Kabupaten Soppeng Sulawesi Selatan dan bahan-bahan kimia yang dibeli dari toko kimia di Makassar.

\subsection{Prosedur Penelitian}

\subsubsection{Persiapan Sampel}

Buah pisang raja pada tingkat kematangan masak (mature) disortasi dan dikupas. Daging buah pisang kemudian dibelah menjadi dua bagian dan dikeringkan pada suhu $60^{\circ} \mathrm{C}$ menggunakan oven blower selama 24 jam, sehingga diperoleh sale pisang raja yang siap diberi perlakuan (tanpa pengemasan, pengemasan menggunakan kemasan HDPE, dan pengemasan vakum HDPE). Sale pisang yang telah dikemas kemudian disimpan pada suhu ruang $\left(28^{\circ} \mathrm{C}-\right.$ 
$30^{\circ} \mathrm{C}$ ) selama 28 hari dan dianalisa kimia dan uji organeleptik setiap 7 hari penyimpanan.

\subsubsection{Analisa Kimia}

Analisa kadar air diuji berdasarkan metode oven (Sudarmadji, Haryono, \& Suhardi, 1997). Analisa kadar abu diuji berdasarkan metode tanur (Sudarmadji, dkk., 1998). Analisa gula reduksi diuji berdasarkan metode Luff Schrool (Sudarmadji, dkk., 1998). Dan analisa kadar $\mathrm{pH}$ diuji menggunakan $\mathrm{pH}$ meter (Hadiwiyoto, 1994).

\subsubsection{Uji Organoleptik}

Uji organoleptik dilakukan berdasarkan uji hedonik atau tingkat kesukaan panelis terhadap sampel. Jumlah panelis yang digunakan dalam penelitian ini sebanyak 15 orang panelis tetap. Setiap panelis diminta mengisi kuisioner yang telah berisi 5 tingkat penilaian berdasarkan tingkat kesukaannya terhadap sampel yaitu: 1 (sangat tidak suka), 2 (tidak suka), 3 (agak suka), 4 (suka), dan 5 (sangat suka).

\subsubsection{Analisa Statistik}

Penelitian ini disusun berdasarkan metode rancangan acak lengkap (RAL) faktorial dengan dua faktor yaitu: faktor kemasan, yang terdiri dari tiga taraf perlakuan yaitu tanpa kemasan, pengemasan menggunakan HDPE, pengemasan vakum deangan menggunakan HDPE. Faktor kedua adalah lama penyimpanan pada suhu ruang dengan lima taraf perlakuan yaitu penyimpanan $0,7,14,21$ dan 28 hari. Sampel masing-masing dianalisa sebanyak tiga kali ulangan dan data hasil analisa diolah dengan menggunakan SPSS versi 22. Apabila hasilnya berbeda nyata maka akan dilanjutkan dengan uji Duncan (BNJD).

\section{HASIL DAN PEMBAHASAN}

\subsection{Kadar Air}

Gambar 1 menunjukkan, bahwa kadar air sale pisang setelah 28 hari penyimpanan dengan perlakuan tanpa kemasan mengalami peningkatan kadar air sebesar 4,94\%, sedangkan kadar air sale pisang yang disimpan dengan kemasan tanpa vakum mengalami peningkatan sebesar $3,04 \%$, dan kadar air sale pisang yang disimpan dengan kemasan vakum mengalami peningkatan sebesar $1,46 \%$

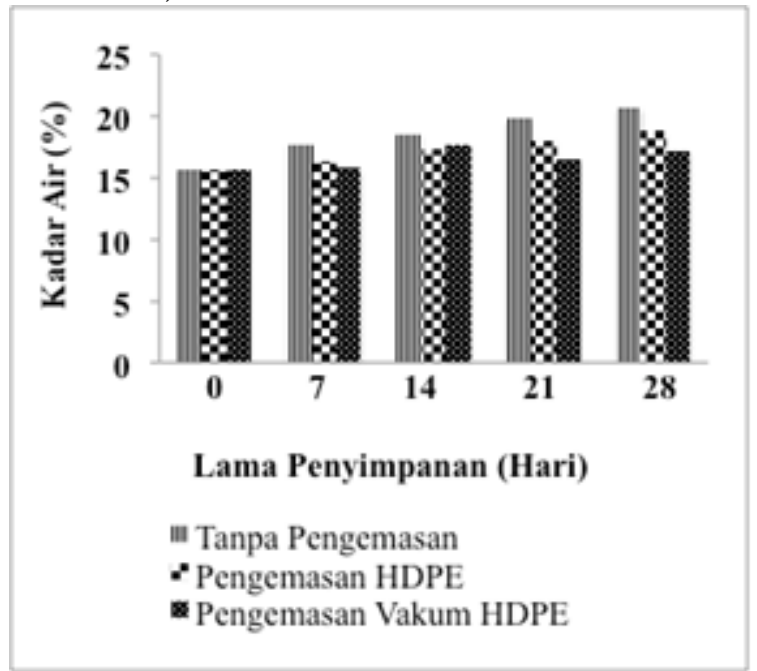

Gambar 1. Hubungan Interaksi

Pengemasan dan Lama Penyimpanan Sale Pisang terhadap Kadar Air.

Hasil analisa sidik ragam menunjukkan, bahwa perlakuan pengemasan, perlakuan lama penyimpanan dan interaksinya berpengaruh sangat nyata terhadap kadar air sale pisang $(\mathrm{P}<0,01)$. Dan berdasarkan hasil uji lanjut Duncan bahwa ketiga perlakuan pengemasan berbeda, begitupun perlakuan penyimpanan menunjukkan perbedaan antara 0 hari penyimpanan dengan 7 hari dan 28 hari penyimpanan, tetapi penyimpanan 14 hari tidak berbeda dengan penyimpanan 21 hari.

Sale pisang yang disimpan tanpa dikemas terjadi penyerapan uap air kembali dari udara lingkungan penyimpanan ke dalam sale pisang, sehingga menyebabkan kadar air menjadi meningkat. Tingginya kadar air ini menyebabkan mutu sale pisang tanpa kemasan menurun. Sale pisang yang dikemas vakum masih memiliki mutu yang lebih baik dibandingkan dengan perlakuan lain, karena udara di dalam kemasan ditarik keluar dan adanya kemasan dapat menghambat masuknya uap air dari udara ke 
dalam produk. Hal ini sesuai dengan (Habibah, Fachraniah, \& Fona, 2006) yang menyatakan, bahwa penurunan mutu sale pisang disebabkan karena adanya peningkatan kadar air dari lingkungan ke dalam bahan pangan. Penurunan mutu sale pisang ini dapat dikurangi dengan menggunakan pengemasan, karena pengemasan dapat mengurangi kontak langsung antara bahan pangan dengan lingkungan sehingga dapat mempertahankan mutu sale pisang.

Penurunan mutu sale pisang juga dipengaruhi oleh lama penyimpanan. Semakin lama penyimpanan, maka kadar air sale pisang semakin meningkat. Hal ini disebabkan karena sale pisang bersifat mudah menyerap air yang ada di sekeliling lingkungan penyimpanannya. Banyaknya penyerapan air akan memicu pertumbuhan khamir atau kapang, sehingga mutu sale pisang semakin lama semakin menurun. Hal ini sesuai dengan (Prabawati, 2008) yang menyatakan, bahwa daya simpan sale pisang dapat dipengaruhi oleh lingkungan penyimpanan sale tersebut. Sale pisang merupakan produk yang bersifat mudah menyerap air. Penyerapan uap air dari udara sekeliling akan menaikkan kadar air sale pisang, sehingga sale pisang akan mudah terinfeksi oleh khamir atau kapang.

\subsection{Kadar Abu}

Gambar 2 menunjukkan, bahwa kadar abu sale pisang setelah 28 hari penyimpanan dengan perlakuan tanpa kemasan mengalami peningkatan kadar abu sebesar $0,86 \%$, sedangkan sale pisang yang disimpan dengan kemasan tanpa vakum mengalami peningkatan sebesar $0,75 \%$, dan sale pisang yang disimpan dengan kemasan vakum mengalami peningkatan sebesar $0,68 \%$.

Hasil analisa sidik ragam menunjukkan, bahwa perlakuan pengemasan dan penyimpanan berpengaruh sangat nyata terhadap kadar abu $(\mathrm{P}>0,01)$. Dan berdasarkan hasil uji lanjut Duncan, sale pisang yang dikemas baik divakum maupun tidak divakum berbeda dengan sale pisang yang tidak dikemas. Sedangkan hasil uji lanjut Duncan sale pisang selama penyimpanan berbeda dari hari ke-0 sampai hari ke-28. Hal ini disebabkan karena karbohidrat pada sale pisang pada saat penyimpanan terhidrolisis menjadi senyawa-senyawa lain, termasuk mineral sehingga akan meningkatkan kadar abu. Hal ini sesuai dengan (Affandi; \& Heru, 2011), bahwa tingginya kandungan karbohidrat dapat diubah menjadi asam organik dan terhidrolisis menjadi senyawa-senyawa lain, termasuk mineral yang akan meningkatkan kadar abu.

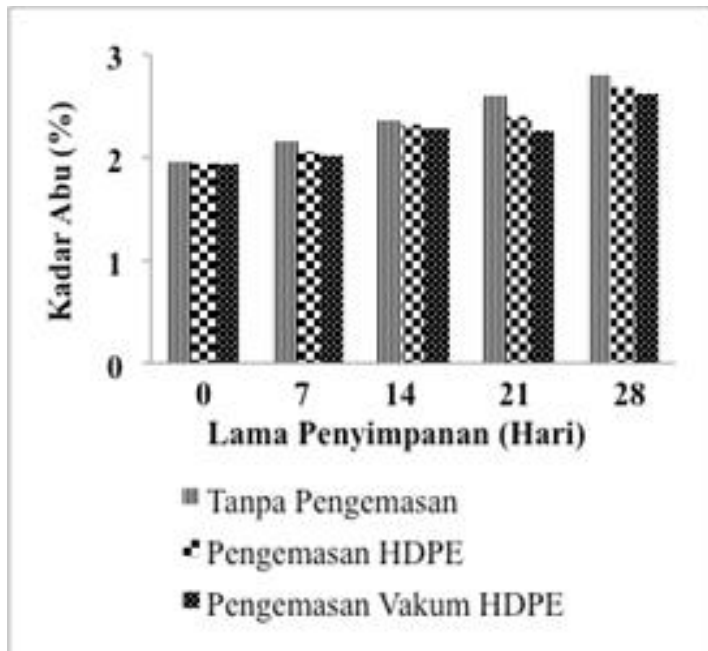

Gambar 2. Hubungan Interaksi Pengemasan dan Lama Penyimpanan Sale Pisang terhadap Kadar Abu.

Hasil analisa sidik ragam menunjukkan bahwa interaksi pengemasan dan lama penyimpanan tidak berpengaruh nyata terhadap kadar abu sale pisang $(\mathrm{P}>0,05)$ sehingga uji BNJD tidak dilanjutkan

\subsection{Gula Reduksi}

Gambar 3 menunjukkan, bahwa setelah 28 hari penyimpanan, sale pisang tanpa kemasan mengalami penurunan gula reduksi sebesar $1,89 \%$, sedangkan untuk perlakuan penyimpanan dengan kemasan tanpa vakum mengalami penurunan gula reduksi sebesar $1,61 \%$, dan perlakuan penyimpanan dengan kemasan vakum mengalami penurunan gula reduksi sebesar $1,70 \%$. 


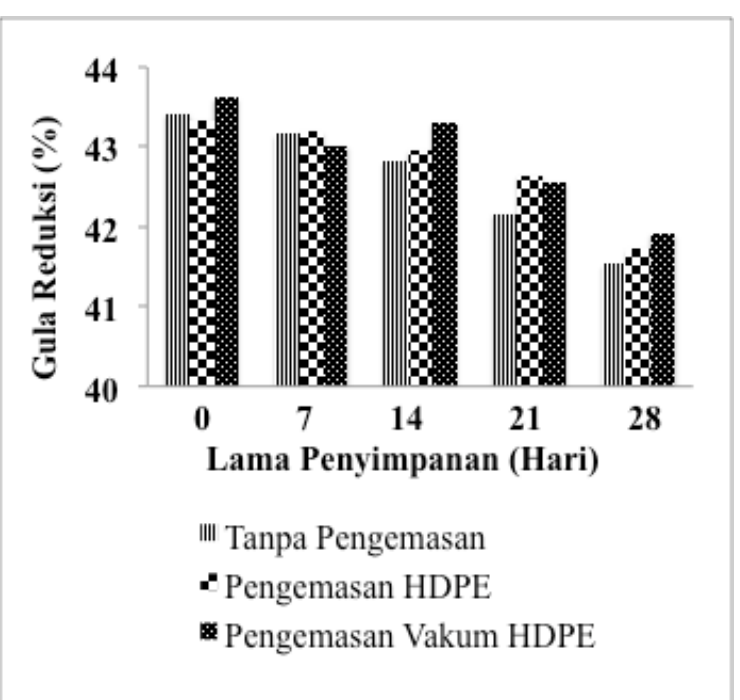

Gambar 3. Hubungan Interaksi Pengemasan dan Lama Penyimpanan Sale Pisang terhadap Gula Reduksi.

Hasil analisa sidik ragam menunjukkan, bahwa perlakuan pengemasan tidak berpengaruh nyata terhadap gula reduksi sale pisang $(\mathrm{P}>0,05)$. Sedangkan lama penyimpanan berpengaruh sangat nyata terhadap gula reduksi sale pisang $(\mathrm{P}<0,01)$. Dan berdasarkan hasil uji lanjut Duncan penyimpanan hari ke-0 dan hari ke-28 berbeda dengan hari ke-7, 14 dan 21. Tetapi lama penyimpanan hari ke-14 dan hari ke-21 tidak berbeda begitupun penyimpanan hari ke-7 dan hari ke-14.

Penurunan gula reduksi sale pisang berhubungan dengan adanya peningkatan kadar air pada sale pisang selama penyimpanan. Dengan peningkatan kadar air maka mikroorganisme seperti kapang lebih mudah tumbuh karena memanfaatkaan gula reduksi pada sale pisang untuk pertumbuhannya yang dapat menyebabkan gula reduksi menurun. Hal ini sesuai dengan (Andarti \& Agustin, 2015) yang menyatakan, bahwa penurunan gula pereduksi dikarenakan mikroba menggunakan gula pereduksi sebagai makanan untuk pertumbuhannya. Semakin lama penyimpanan, kandungan gula reduksi semakin menurun.

Interaksi antara pengemasan dan lama penyimpanan terhadap gula reduksi sale pisang menunjukkan adanya penurunan gula reduksi setelah 28 hari penyimpanan. Hasil analisa sidik ragam menunjukkan bahwa interaksi pengemasan dan lama penyimpanan tidak berpengaruh nyata terhadap gula reduksi sale pisang $(\mathrm{P}>0,05)$ sehingga uji BNJD tidak dilanjutkan. Hal ini menunjukan bahwa penggunaan kemasan tidak mempengaruhi perubahan gula reduksi sale pisang selama penyimpanan.

\subsection{Nilai pH}

Gambar 4 menunjukkan, bahwa setelah 28 hari penyimpanan, sale pisang tanpa kemasan mengalami peningkatan $\mathrm{pH}$ sebesar 0,46, sedangkan dengan kemasan tanpa vakum mengalami peningkatan $\mathrm{pH}$ sebesar 0,36, dan perlakuan dengan kemasan vakum mengalami peningkatan $\mathrm{pH}$ sebesar 0,37 .

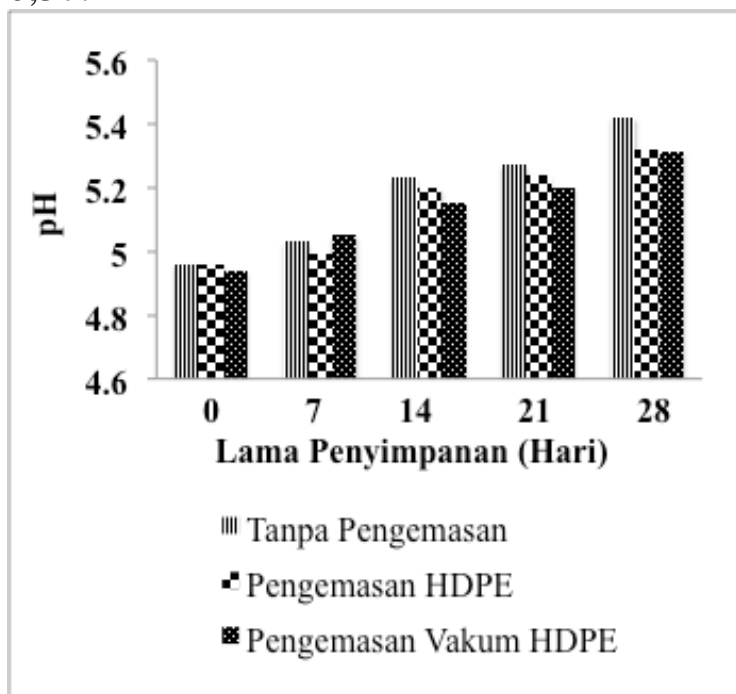

Gambar 4. Hubungan Interaksi Pengemasan dan Lama Penyimpanan Sale Pisang terhadap $\mathrm{pH}$.

Hasil analisa sidik ragam menunjukkan bahwa perlakuan pengemasan dan interaksi antara pengemasan dan lama penyimpanan tidak berpengaruh terhadap $\mathrm{pH}$ sale pisang $(\mathrm{P}>0,05)$. Sedangkan perlakuan lama penyimpanan berpengaruh sangat nyata terhadap $\mathrm{pH}$ sale pisang $(\mathrm{P}<0,01)$. Dan berdasarkan hasil uji lanjut Duncan, penyimpanan 28 hari berbeda dengan penyimpanan $0,7,14$ dan 21 hari. Tetapi penyimpanan 0 hari tidak berbeda 
dengan penyimpanan 7 hari, begitupun penyimpanan 14 hari tidak berbeda dengan penyimpanan 21 hari.

Selama penyimpanan pada suhu ruang, $\mathrm{pH}$ sale pisang semakin meningkat akibat adanya aktivitas mikroorganisme perusak yang dapat menurunkan mutu sale pisang. Dengan meningkatnya aktivitas dan pertumbuhan mikroorganisme maka semakin cepat kerusakan yang terjadi pada sale pisang dan akan mempengaruhi mutu organoleptiknya. Meskipun nilai $\mathrm{pH}$ sale pisang meningkat tetapi masih pada kondisi asam. Hal ini sesuai dengan (Wicaksono, Jayus, Abdullah, Heng, \& Ahmad, 2011) yang menyatakan, bahwa semakin lama penyimpanan pada suhu ruang akan semakin banyak basa yang dihasilkan akibat semakin meningkatnya aktivitas mikroorganisme yang pada akhirnya mengakibatkan terjadinya pembusukan. Proses pembusukan akan diikuti dengan peningkatan $\mathrm{pH}$, dan keadaan ini akan diikuti pula dengan peningkatan pertumbuhan mikroba.

\subsection{Uji Organoleptik Sale Pisang}

\subsubsection{Warna}

Gambar 5 menunjukkan bahwa setelah 28 hari penyimpanan, nilai organoleptik warna pada perlakuan pengemasan vakum menurun dari 4,51 (sangat suka) pada hari ke-0 penyimpanan menjadi 3,64 (suka), sedangkan perlakuan pengemasan tanpa vakum menurun dari 4,42 (suka) menjadi 3,48 (agak suka), dan pada perlakuan tanpa kemasan menurun dari 4,37 (suka) menjadi 2,93 (agak suka).

Hasil analisa sidik ragam menunjukkan bahwa perlakuan pengemasan dan lama penyimpanan memberikan pengaruh nyata terhadap warna sale pisang $(\mathrm{P}<0,05)$, sedangkan interaksi antara kedua perlakuan tidak berpengaruh nyata terhadap warna sale pisang $(\mathrm{P}>0,05)$.

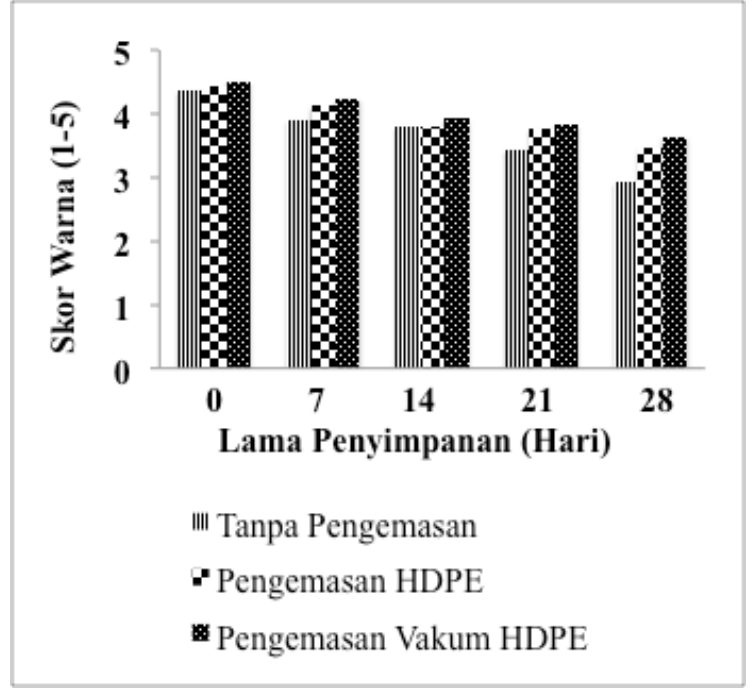

Gambar 5. Hubungan Interaksi

Pengemasan dan Lama Penyimpanan Sale Pisang terhadap Warna.

Sale pisang yang disimpan tanpa kemasan mengalami perubahan warna menjadi semakin coklat kehitaman. Semakin lama penyimpanan maka warnanya semakin gelap sehingga mengurangi penilaian panelis terhadap sale pisang yang disajikan. Perubahan warna sale pisang selama penyimpanan berhubungan dengan meningkatnya kadar air dalam sale pisang. Semakin meningkatnya kadar air selama penyimpanan maka warna sale pisang juga akan semakin berwarna gelap, sehingga mengurangi tingkat kesukaan panelis terhadap sale pisang selama penyimpanan. Sedangkan sale pisang yang dikemas vakum lebih disukai panelis karena pengemas vakum dapat menghambat penyerapan uap air sehingga warnanya lebih disukai panelis. Hal ini sesuai dengan Vemulapalli \& Hoseney (1998), yang menyatakan bahwa migrasi uap air yang tinggi akan mengakibatkan warna produk menjadi lebih gelap.

\subsubsection{Aroma}

Gambar 6 menunjukkan bahwa setelah 28 hari penyimpanan, nilai organoleptik aroma pada perlakuan pengemasan vakum menurun dari 4,55 (sangat suka) pada hari ke-0 penyimpanan menjadi 3,48 (agak suka), 
sedangkan perlakuan pengemasan tanpa vakum menurun dari 4,51 (sangat suka) menjadi 3,24 (agak suka), dan pada perlakuan tanpa kemasan menurun dari 4,44 (suka) menjadi 2,58 (tidak suka).

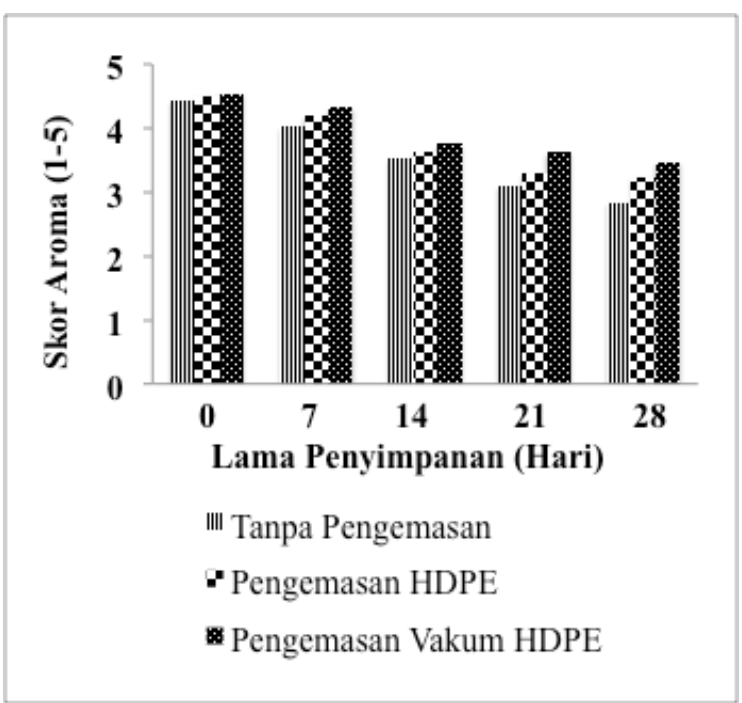

Gambar 6. Hubungan Interaksi Pengemasan dan Lama Penyimpanan Sale Pisang terhadap Aroma

Hasil analisa sidik ragam menunjukkan bahwa perlakuan pengemasan dan perlakuan lama penyimpanan berpengaruh sangat nyata terhadap aroma sale pisang $(\mathrm{P}<0,01)$. Sedangkan interaksi antara pengemasan dan lama penyimpanan tidak berpengaruh terhadap nilai organoleptik aroma sale pisang $(\mathrm{P}>0,05)$.

Aroma sale pisang tanpa kemasan mengalami penurunan tingkat kesukaan yang lebih rendah dibandingkan dengan perlakuan lain. Penurunan aroma juga berkaitan dengan meningkatnya kadar air pada sale pisang. Dengan meningkatnya kadar air maka mikroorganisme perusak semakin mudah tumbuh dan menyebabkan timbulnya aroma yang menyimpang. Ratarata panelis menilai ada sedikit perubahan aroma pada sale pisang. Sedangkan sale pisang dengan kemasan vakum memiliki aroma sale pisang yang masih khas. Hal ini disebabkan karena pengemasan dapat mempertahankan mutu produk serta menghambat kerusakannya dibandingkan dengan produk tanpa dikemas. Hal ini sesuai dengan (Nur, 2009), yang menyatakan bahwa dengan adanya pengemasan vakum maka kontak antara produk yang dikemas dengan udara sekeliling dapat dikurangi, sehingga dapat mengurangi jumlah mikroorganisme yang berkembang dan akhirnya proses dekomposisi yang menyebabkan perubahan aroma akan terhambat.

\subsubsection{Rasa}

Gambar 7 menunjukkan bahwa setelah 28 hari penyimpanan, nilai organoleptik rasa pada perlakuan pengemasan vakum menurun dari 4,62 (sangat suka) pada hari ke-0 penyimpanan menjadi 3,86 (suka), sedangkan perlakuan pengemasan tanpa vakum menurun dari 4,53 (sangat suka) menjadi 3,60 (suka), dan pada perlakuan tanpa kemasan menurun dari 4,51 (sangat suka) menjadi 3,06 (agak suka).

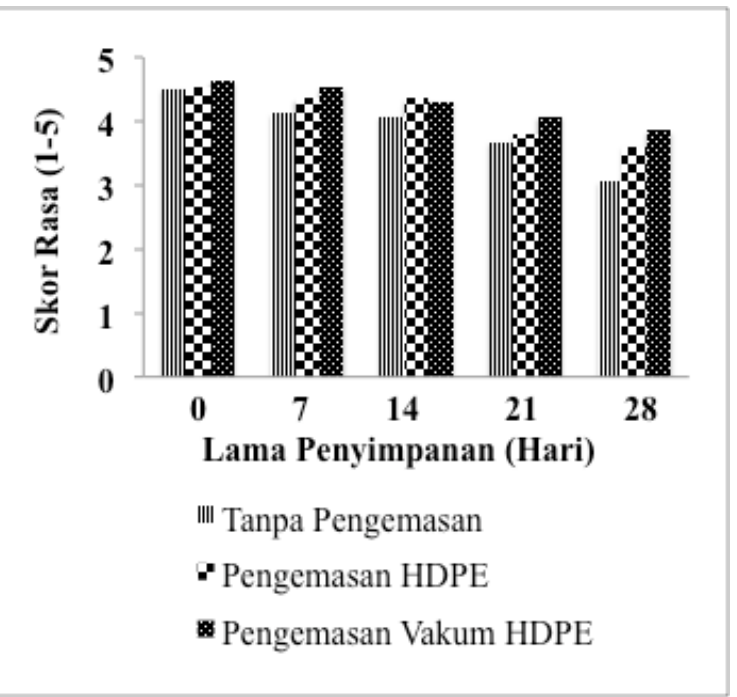

Gambar 7. Hubungan Interaksi Pengemasan dan Lama Penyimpanan Sale Pisang terhadap Rasa

Hasil analisa sidik ragam menunjukkan, bahwa perlakuan pengemasan dan perlakuan lama penyimpanan berpengaruh sangat nyata terhadap rasa sale pisang $(\mathrm{P}<0,01)$.

Penurunan tingkat kesukaan rasa berhubungan dengan penurunan kadar gula reduksi sale pisang. Sale pisang yang tidak dikemas lebih mudah terkontaminasi oleh 
mikroorganisme sehingga menyebabkan perubahan rasa sale pisang. Sedangkan pada sale pisang yang dikemas vakum pertumbuhan mikroorganisme dapat terhambat karena gas dan uap air ditarik keluar dari dalam kemasan sehingga kerusakannya lebih rendah dan mempunyai mutu yang lebih baik dibandingkan dengan perlakuan lain. Hal ini sesuai dengan (Syarief \& Halid, 1993)yang menyatakan, bahwa pengemasan vakum cenderung menekan pertumbuhan mikroorganisme, perubahan rasa, serta penampakan selama penyimpanan, karena pada kondisi vakum, mikroorganisme aerob yang tumbuh jumlahnya relatif lebih kecil dibanding dalam kondisi tidak vakum.

Interaksi antara pengemasan dan lama penyimpanan terhadap rasa sale pisang dari hasil analisa sidik ragam menunjukkan hasil yang tidak berpengaruh nyata $(\mathrm{P}>0,05)$. Penurunan tingkat kesukaan panelis terhadap rasa sale pisang setelah 28 hari penyimpanan disebabkan karena adanya aktivitas mikroorganisme terutama pada sale pisang yang tidak dikemas sehingga terjadi perubahan komponen pada bahan yang dapat mempengaruhi rasa sale pisang. Hal ini sesuai dengan (Buckel, Purnomo, Adini, \& Tinggi, 2013) yang menyatakan, bahwa faktor suhu, kelembaban, oksidasi dan aktifitas mikroorganisme dapat merombak kandungan molekul bahan yang menyebabkan terjadinya perubahan rasa.

\subsubsection{Tekstur}

Gambar 8 menunjukkan bahwa setelah 28 hari penyimpanan, nilai organoleptik tekstur pada perlakuan pengemasan vakum menurun dari 4,42 (suka) pada hari ke-0 penyimpanan menjadi 3,93 (suka), sedangkan perlakuan pengemasan tanpa vakum menurun dari 4,35 (suka) menjadi 3,51 (suka), dan pada perlakuan tanpa kemasan menurun dari 4,42 (suka) menjadi 3,04 (agak suka).

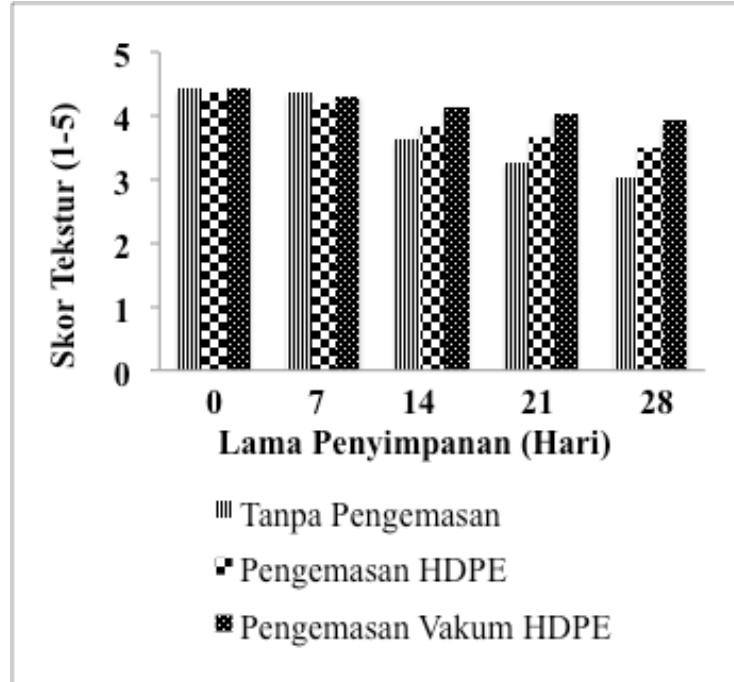

Gambar 8. Hubungan Interaksi Pengemasan dan Lama Penyimpanan Sale Pisang terhadap Tekstur

Hasil analisa sidik ragam menunjukkan, bahwa perlakuan pengemasan dan perlakuan lama penyimpanan berpengaruh sangat nyata terhadap tekstur sale pisang $(\mathrm{P}<0,01)$. Adanya pengemasan sangat berpengaruh terhadap tekstur sale pisang karena sale pisang yang tidak dikemas teksturnya semakin lama menjadi semakin lunak akibat terjadinya peningkatan kadar air. Kadar air merupakan salah satu faktor yang mempengaruhi tekstur sale pisang, semakin tinggi kadar air maka tekstur sale pisang semakin lunak. Perubahan tektur ini dapat mempengaruhi mutu sale pisang serta tingkat kesukaan panelis. Sedangkan tekstur sale pisang yang dikemas vakum lebih baik dibandingkan dengan perlakuan lain karena pada kondisi vakum akan menghambat sirkulasi udara dan uap air yang menyebabkan pelunakan tekstur sale pisang. Hal ini sesuai dengan (Habibah et al., 2006) yang menyatakan, bahwa kriteria kerusakan sale pisang adalah peningkatan kadar air sehingga untuk mencegah peningkatan kadar air maka diperlukan kemasan yang tahan terhadap uap air.

Hasil analisa sidik ragam menunjukkan bahwa interaksi pengemasan dan lama penyimpanan berpengaruh sangat nyata terhadap rasa sale pisang $(\mathrm{P}<0,01)$. Sale pisang yang disimpan selama 28 hari dengan 
perlakuan tanpa kemasan memiliki tekstur yang kurang disukai panelis. Hal ini disebabkan karena sale pisang tanpa kemasan pada penyimpanan 28 hari memiliki tekstur yang lebih lunak dibandingkan pada saat penyimpanan 0 hari. Perubahan tekstur ini disebabkan karena sale pisang yang tidak dikemas menyerap air dari lingkungan penyimpanan sehingga semakin lama disimpan maka teksturnya semakin lunak. Sedangkan sale pisang yang dikemas vakum memiliki tekstur yang lebih disukai panelis karena penyerapan air dapat terhambat karena adanya pengemasan vakum. Hal ini sesuai dengan Purnomo (1995), bahwa faktor yang dapat mempengaruhi tekstur antara lain adalah kadar air, kandungan protein, suhu, dan aktivitas dari pergerakan air.

\section{KESIMPULAN}

Kesimpulan dari hasil penelitian adalah sale pisang yang dikemas vakum memiliki mutu kimia dan organoleptik yang lebih baik dibandingkan dengan sale pisang tanpa dikemas dan sale pisang yang dikemas tanpa vakum.

\section{DAFTAR PUSTAKA}

Affandi;, \& Heru. (2011). Pemanfaatan Limbah Ampas Kelapa Sawit sebagai Substrat Untuk Sintesis Zat Gizi melalui Fermentasi Kapang Rhizopus oligosporus. The Journal of Nurition and Food Research, 34(2), 123-130.

Andarti, \& Agustin. (2015). Pengaruh Lama Fermentasi terhadap Karakteristik Kimia, Mikrobiologi, dan Organoleptik Miso Kedelai Hitam (Glycine max (L)). Jurnal Pangan Dan Agroindustri, 3(3), 889-898.

Buckel, Purnomo, Adini, \& Tinggi, D. jendral pendidikan. (2013). Ilmu Pangan. Jakarta: Penerbit universitas Indonesia.

Habibah, U., Fachraniah, Z., \& Fona, E. (2006). Penggunaan Metode
Akselerasi Pada Penentuan Umur Simpan Pisang Sale Dengan Pengemas Yang Berbeda-Beda. Jurnal Reaksi (Journal of Science and Technology) Jurusan Teknik Kimia Politeknik Negeri Lhokseumawe, 4(7), 1-6. Hadiwiyoto. (1994). Teori dan Prosedur Pengujian Mutu Susu dan Hasil Olahannya. Edisi II. Yogyakarta: Liberty.

Nur, M. (2009). Pengaruh Cara

Pengemasan, Jenis Bahan Pengemas, dan Lama Penyimpanan terhadap Sifat Kimia, Mikrobiologi, dan Organoleptik Sate Bandeng (Chanos chanos). Jurnal Teknologi Dan Industri Hasil Pertanian, 14(1), 3437.

Prabawati, S., Suyanti \& Satyabudi, D. A. (2008). Teknologi Pasca Panen dan Teknik Pengolahan Buah Pisang. Bogor, Balai Besar Penelitan dan Pengembangan Pascapanen Pertanian, Badan Penelitan dan Pengembangan Pertanian Pisang).

Satuhu, \& Supriyadi. (1992). Pisang: Budidaya, Pengolahan dan prospek Pasar. Jakarta, Indonesia: Penebar Swadaya.

Sudarmadji, Haryono, S. B., \& Suhardi. (1997). Prosedur Analisis Bahan Makanan dan Pertanian. Yogyakarta: Liberty.

Syarief, \& Halid. (1993). Teknologi

Penyimpanan Pangan. Jakarta: Arcan Press.

Sudarmadji, S., Haryono, B., \& Suhardi (1998). Prosedur Analisa Untuk Bahan Makanan dan Pertanian. Bandung, Penerbit Angkasa.

Wicaksono, Y., Jayus, Abdullah, A., Heng, L. Y., \& Ahmad, M. (2011). Smart packaging: Sensors for monitoring of food quality and safety. Sensing and Instrumentation for Food Quality and Safety, 5(3-4), 137-146. https://doi.org/10.1007/s116 94-0119120-x 